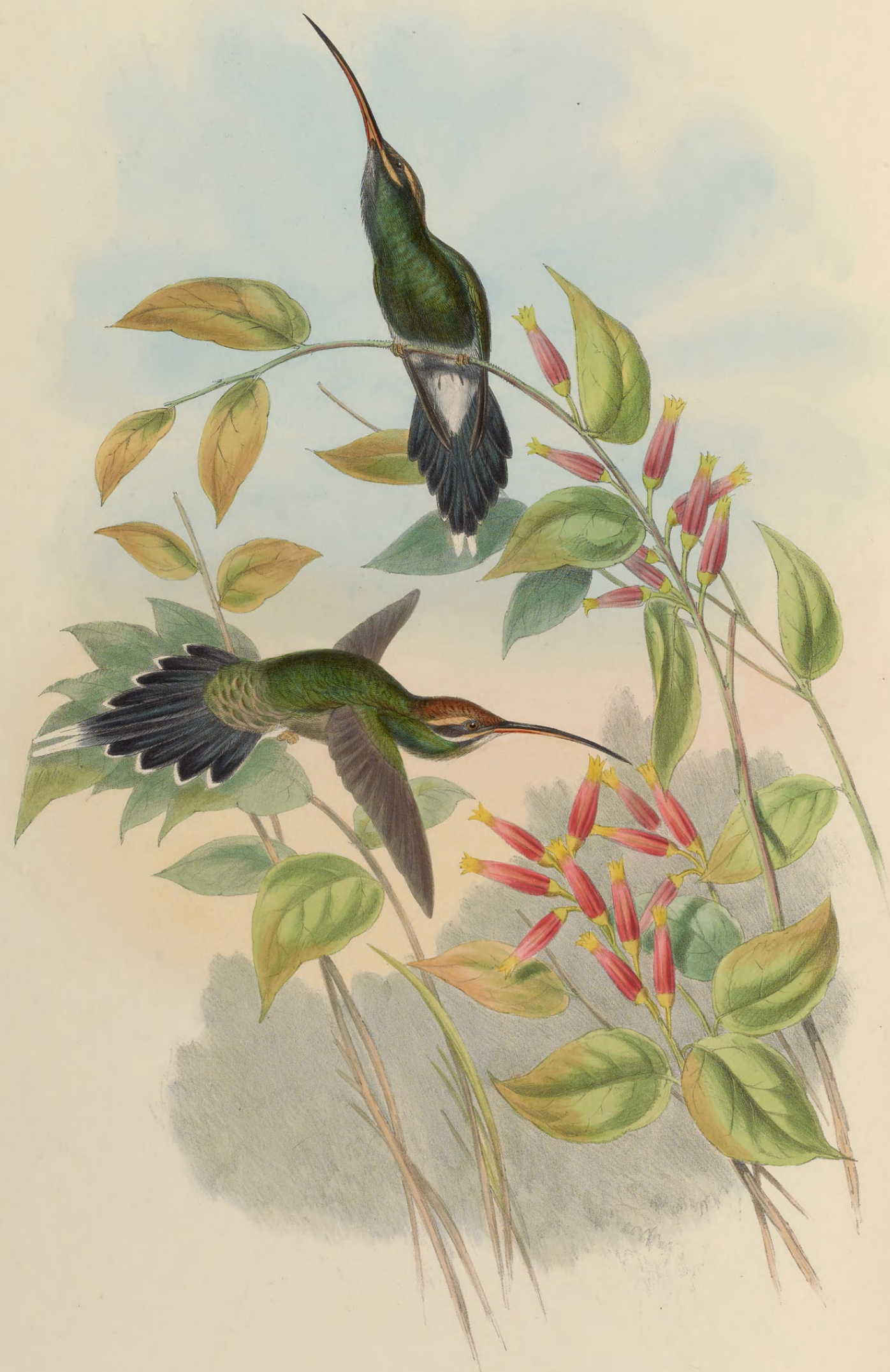

PHIAL:"THIORNIS YARUGUI. 


\title{
PHAËTHORNIS YARUQUI.
}

\section{Yaruquian Hermit.}

\author{
Trochilus Yaruqui, Bourc., Compte Rendu de l'Acad. des Sci., tom. xxxii. p. 187.
}

This fine new species of Phaëthornis is a native of the temperate regions of Ecuador, whence several examples were brought to Europe by M. Bourcier; and my own collection has been enriched by some fine specimens transmitted to me from Quito by Professor Jameson. It appears to be very common in the neighbourhood of the city, and particularly in the valley of Yaruqui, in which the French Academicians in 1742 placed the point from whence they measured an arc of the meridian, and where it dwells amidst the small bushes skirting the forest, but appears to give a preference to the shady parts of the woods bordering the warmer plains, where it seeks its insect food among the Orchids and other flowering plants growing in such situations. Its flight is described as being gentle, and its disposition as very tame. Its broad and nearly uniform steel-black tail at once distinguishes it from Phaëthornis Guy, to which it is nearly allied. Like that bird, it is subject to considerable variation in the form of the tail, that organ being much more lengthened in some instances than in others; the longer tailed specimens also have the lateral feathers fringed, and the two central ones extensively tipped with white. That the birds in this state are immature, is shown by the brown crescentic marks on the feathers of the back of the head and upper surface, which are entirely absent in those having the shorter and more rounded form of tail, with the lateral feathers of a uniform colour. The central tail-feathers are always broader and much more obtusely pointed than those of $P$. Guy. In some specimens we find a deep rufous mark, commencing above and behind the eye to the nape; a second fainter line from the gape down the side of the neck, and a third occupying tne centre of the throat, as in $\boldsymbol{P}$. Guy; but these marks do not occur in very old birds.

Head bronzy brown; upper and under surface and wing-coverts shining green; wings dark purplish black; upper tail-coverts green, with a crescent of black, and another of white at the tip; tail bluish black ; the two central feathers tipped with white, and the next on each side with a small speck of white at the tip; under tail-coverts white, with a streak of black near the tip of each feather; upper and point of the lower mandible black; basal two-thirds of the lower mandible fleshy red; feet yellowish brown.

In the immature state, the colouring of the upper surface is interrupted by crescentic marks of brown; the central tail-feathers are more largely tipped, and the lateral ones are fringed at their ends with white; there is a deep buffy mark above, and a paler one beneath the eye, and a small mark of white on the chin.

The figures are of the natural size, on the Macleania angulata. 


\section{$2 \mathrm{BHL}$ Biodiversity Heritage Library}

Gould, John. 1851. "Phaëthornis yaruqui, Yaruquian Hermit. [PI. 27]." A monograph of the Trochilidae, or family of humming-birds 1, https://doi.org/10.5962/p.316835.

View This Item Online: https://www.biodiversitylibrary.org/item/108333

DOI: https://doi.org/10.5962/p.316835

Permalink: https://www.biodiversitylibrary.org/partpdf/316835

\section{Holding Institution}

Smithsonian Libraries

\section{Sponsored by}

Smithsonian Institution Libraries

\section{Copyright \& Reuse}

Copyright Status: NOT_IN_COPYRIGHT

This document was created from content at the Biodiversity Heritage Library, the world's largest open access digital library for biodiversity literature and archives. Visit BHL at https://www.biodiversitylibrary.org. 